\title{
Vitamin D Supports $\beta$-Cell Remodeling Capacity and Could Reduce High Fat Diet-Induced Insulinitis in Pups Born to Diabetic Mothers
}

\author{
ASMAA M. SHAMS EL-DEEN, M.D.*; MANAL MOUSTAFA, M.D.*; MARWA F. AMER, M.D.**; \\ GEORGE N. MORCOS, M.D.** and HANAN ABDALLAH, M.D.*** \\ The Departments of Physiology*, Medical Biochemistry \& Molecular Biology** and Medical Histology***, \\ Faculty of Medicine, Cairo University, Egypt
}

\begin{abstract}
Background: Disrupting fetal environment in particular the state of hyperglycemia during the critical period of pancreatic development is one of potential factors that could alter $\beta$-cell function and morphology in adulthood. Vitamin D intake could protect $\beta$-cells from functional impairment and islet cells death.
\end{abstract}

Aim of the Study: Present study aimed to study effect of maternal hyperglycemia on genes regulating insulin-secreting cells development and possible modulating actions of Vitamin D supplementation either during pregnancy or further continuation till weaning, also its possible protection from excess dietary fat intake.

Methods: Twenty four adult female rats were mated and after confirmation of day 0 pregnancy, six of them were considered as control and the remaining eighteen were subjected to STZ-induced gestational diabetes then subdivided into pregnant-STZ, pregnant-STZ-supplied with Vitamin D during pregnancy and pregnant-STZ-supplied with Vitamin $\mathrm{D}$ during pregnancy and lactation till weaning. After weaning, pups born to those mothers were subjected to IPGTT then half of them were sacrificed and the rest were supplied with $45 \%$ HFD for two consecutive weeks.

Results: The results observed up-regulation of Arx unlike Pax 4 and Ngn3 which were down-regulated in pregnant-STZ group together with impairment of IPGTT and reduced area\% of insulin immune-reactivity, these changes were augmented secondary to $45 \%$ intake of HFD. However, modulating impact of Vitamin D was more obvious in pregnant-STZ-supplied with Vitamin D during pregnancy and lactation than pregnantSTZ-supplied with Vitamin D only during pregnancy.

Conclusion: Vitamin D supplementation till time of weaning could affect developmental programming of $\beta$-cells, enhance insulin secretion and protect against HFD-induced insulinitis.

Key Words: $\beta$-cell neogenesis - Vitamin D - Pax 4 - Ngn3 $\beta$-cell remodeling.

Correspondence to: Dr. Asmaa M. Shams El-Deen, E-Mail: asmaa82shamseldeen@gmail.com

\section{Introduction}

GESTATIONAL Diabetes Mellitus (GDM) impairs the intrauterine environment, thus it could affect fetal development leading eventually to functional and structural changes of many tissues including pancreatic islets [1]. Animal studies have shown that offspring of diabetic rats can develop insulin resistant and diabetes [2] . Even more, exposure to mild hyperglycemia during intrauterine life induces fetal hyperinsulinemia, hypertrophy of pancreatic endocrinal part and hyperplasia of the $\beta$-cells [3]. A concept was supported by [4] that developing organs have critical periods of intense structural and functional programing. Excessive stimulation of $\beta$-cells, the stores for insulin could influence its degranulation in fetal life which was described as consequence of severe maternal hyperglycemia [5]. Animals with perinatal hyperinsulinemia could display an impaired glucose tolerance in adulthood [6].

The associated hyperglycemia, hyperlipidemia and the consequent hepatic lipid accumulation in type II DM are the key mediators of lipotoxicityinduced insulin insensitivity $[\mathbf{7 , 8}]$. In addition, increased intra-islet lipid accumulation impairs glucose-stimulated insulin secretion promoting islet inflammation and progressive $\beta$-cell damage leading eventually to $\beta$-cell apoptosis thus accelerating islet failure [9]

Several signaling pathways could affect $\beta$-cell growth, survival and insulin secretion [10]. Pax4, one of Pax family members, is essential for formation of beta-and delta-cells. In ex vivo study forced expression of Pax 4 in mature alpha cells could change it to beta-like cells, even more; in absence of Pax4 the precursor cells develop alpha-cell-like 
fate [11]. The results of previous work showed that selective inhibition of the Arx gene in (3-cells is sufficient to promote the conversion of adult $\alpha$ cells into (3-like cells at any age [12]

During embryogenesis, the primitive pancreatic duct-like cells give rise to islet cells. It is well recognized that $(3$-cell transition from exocrine ducts occurs with the existence pancreatic stem cells in both fetal and postnatal life [13]. Moreover in in-vitro studies during neonatal life, transdifferentiation of pancreatic duct-like cells to (3cells was previously documented to be mediated following overexpress certain growth factors [14] Vitamin D could mediate direct glucose-stimulated insulin secretion from (3-cell via binding to its receptor expressed in pancreatic (3-cells [15]

Thus prompted us to investigate the effect of Vitamin D supplemented diabetic mothers either during pregnancy or continuation of intake till the end of lactation on (3-cell function and morphology of their pups. Furthermore to examine potential effect of Vitamin D on islet cell regulating genes and the possibility of stimulating new (3-cell formation from pancreatic duct. Healthy diet of normal caloric values could increase longevity of 3 -cells, on the contrary consumption of HFD could induce insulinitis therefore we aimed also to investigate potential role of Vitamin D in modulating effects of high fat containing diet.

\section{Material and Methods}

\section{Animals and study design:}

- Twenty four adult female Wister rats aged between 8 and 10 weeks were purchased from the animal house of National Research Center (NRC). The total duration of the study was 10 weeks (from July, 2017 to September, 2017). Following acclimatization, nulliparous female rats were mated following determination of the oestrus phase of their reproductive cycle using vaginal smear. The presence of spermatozoa in vaginal smears indicated day 0 gestation (G0). Following copulation, female rats were housed singly. Then they were randomly divided into four groups: Group I (C) $\mathrm{n}=6$ : Control pregnant rats received single dose of $1 \mathrm{ml}$ saline intraperitoneal.

GDM-induced groups $(n=18)$ at G0 pregnancy following intraperitoeal injection of streptozotocin (STZ) once at a dose of $40 \mathrm{mg} / \mathrm{kg}$ [16]. STZ-injected pregnant rats were divided randomly into: Group II (pregnant-STZ) n=6, Group III [pregnant-STZVit $D(P)] n=6$ : In which pregnant diabetic female rats were supplied with Vitamin D once/day orally using gastric tube, Group IV [pregnant-STZ-Vit D $(\mathrm{P}+\mathrm{L})] \mathrm{n}=6$ : In which pregnant diabetic females were supplied with Vitamin D throughout the duration of pregnancy and lactation (21 days post natal). Fasting Blood Glucose (FBG) was measured regularly and data was recorded for mothers three times, just before and three days following induction of GDM and lastly just before delivery.

- Vitamin D was given from G0 with daily rat equivalent dose of 400IU [17] during pregnancy. Guided by Paget's table [18], a 70kg-human dose is 400IU/day for pregnant female, thus the daily dose of a rat weighing $150 \mathrm{~g}$ was $400 \times 0.018=$ $7.2 \mathrm{IU} /$ day for pregnant female. The human recommended dose during lactation was 4000IU [19] Using Paget's table, the dose was 4000 X $0.018=$ 72IU/day.

\section{Material and reagents for:}

1- Supplementation of Vitamin D was according to the recommended dose during pregnancy and lactation. The form that was given is cholecalciferol (Euro D 10.000IU).

2- Streptozotocin for induction of GDM: Freshly prepared solution was formed of Streptozotocin (STZ) dissolved in $0.1 \mathrm{M}$ citrate buffer ( $\mathrm{pH} 4.5$ ) and injected intraperitoneal. The third day after STZ injection, blood samples were withdrawn from rat tail veins for assuring the development of GDM using a glucometer (GlucoDrTM, all Medicus Co. Ltd, Gyeonggi, Korea). Animals of fasting blood glucose more than $180 \mathrm{mg} / \mathrm{dl}$ were considered diabetic and included the present study.

3- Composition of 45\% HFD: All ingredients were measured in grams according to product dataD12451.

Casein, 30 Mesh: 200, L-Cystine: 3, Corn Starch: 72.8, Maltodextrin 10: 100, Sucrose: 172.8, Cellulose BW200: 50, Soybean Oil: 25, Lard: 177, Mineral Mix S 10026: 10, DiCalcium Phosphate: 13, Calcium Carbonate: 5.5, Potassium Citrate 1 H2O: 16.5, Vitamin Mix V 10001: 10, Choline Bitartrate: 2.

4- Intraperitoneal Glucose Tolerance Test (IPGTT): It was performed twice at 3 and 5 weeks after birth. Offsprings were fasted overnight and injected intraperitoneally with glucose $(2 \mathrm{~g} / \mathrm{kg})$. Blood glucose levels were measured at times offasting (time zero), 15, 30, 60, 120min with a glucometer (GlucoDrTM, all Medicus Co. Ltd, Gyeonggi, Korea). 
Number of offsprings: The total number of offsprings was 65, 17 in C group, 16 in Group II and 17 in Group III and 15 in Group IV. By the age of 3 weeks, all pups were subjected to IPGTT, then half of them were sacrificed using high dose of phenobarpitone. The rest of animals were supplied with HFD of $45 \%$ calories derived from animal source for another 2 weeks. Then the animals were subjected to IPGTT on the day scarification.

\section{Scarification and sample collection:}

Immediately before scarification, blood samples were withdrawn through retro-orbital route using capillary tubes one sample was collected in $10 \mathrm{ml}$ Eppendorf tubes and the other was collected in EDTA-tubes for detection of insulin concentration. Samples were separated by centrifugation at 5000 rpm for 10 minutes and biochemically estimated for the following parameters.

\section{Serum cholesterol and Triglyceride (TG) levels:}

Both were measured using the conventional colorimetric method directly using QuantiChrom TM assay kit (Corporate Place; Hayward; USA).

\section{Insulin levels:}

That was measured using ELISA kit supplied by (DRG, USA) in accordance with manufacturer's instruction.

\section{Malondialdehyde (MDA):}

MDA concentration was measured guided by Wills instructions in 1987 [20], 100mg of pancreatic tissues were homogenized in $1 \mathrm{~mL}$ Phosphate Buffer Saline (PBS) at pH 7.0 with micro-pestle in microtube. $20 \%$ TCA was added to tissue homogenate to precipitate the protein, and centrifuged. Supernatants were collected then Thiobarbituric Acid (TBA) solution was added to the supernatants. The absorbance was measured after boiling in water bath for 10 minutes. Lastly, concentration of MDA in supernatants of homogenate was calculated using the standard.

Tissue samples: Pancreatic tissues of the pups were excised and prepared for:

Biochemical detection of relative gene expression levels of:

A- Pax4, Arx and Neurogenin (Ngn3).

B- B-cell lymphoma-extra large (BCL-xl).

C- Nuclear factor- $\kappa B(N F-\kappa B)$.
In accordance with the following steps:

Detection of relative gene expression by real time PCR:

- Total RNA extraction: SV Total RNA Isolation System (Promega, Madison, WI, USA) was used for total RNA extraction from tissue homogenate in according to manufacturer's instruction. The RNA concentrations and purity were measured with an ultraviolet spectrophotometer.

- Complementary DNA (cDNA) synthesis: $\mathrm{cD}$ NA was synthesized from 1 RA using SuperScript III First-Strand Synthesis System as described in the manufacturer's protocol (\#K1 621, Fermentas, Waltham, MA, USA). 1 ototal RNA was mixed with 50 Matigo (dT) 20,50ng/ random primers, and $10 \mathrm{mMdNTP}$ mix in a total volume of 10 The mixture was incubated at $56^{\circ} \mathrm{C}$ for $5 \mathrm{~min}$ then placed on ice for $3 \mathrm{~min}$. The reverse transcriptase master mix containing 2 I a of 10X RT buffer, 4 mM MgCl2, 25 a $0.1 \mathrm{M}$ DTT, and 1 Le SuperScript ${ }^{\circledR}$ III RT (200U/L) as added to the mixture and incubated at $25^{\circ} \mathrm{C}$ for $10 \mathrm{~min}$ followed by $50 \mathrm{~min}$ at $50^{\circ} \mathrm{C}$.

- Real-time quantitative PCR: Real-time PCR amplification and analysis were performed using an Applied Biosystem with software version 3.1 (StepOneTM, USA). The reaction contained SYBR Green Master Mix (Applied Biosystems), genespecific primer pairs (Table 1) were designed with Gene Runner Software (Hasting Software, Inc., Hasting, NY) from RNA sequences from the gene bank. All primer sets had a calculated annealing temperature of $60^{\circ}$. Quantitative RT-PCR was performed in a 25- renction volume consisting of 2X SYBR Green PCR Master Mix (Applied Biosystems), $900 \mathrm{nM}$ of each primer and 2 Lof cDNA. Amplification conditions were: $2 \mathrm{~min}$ at $50^{\circ}, 10 \mathrm{~min}$ at $95^{\circ}$ and 40 cycles of denaturation for $15 \mathrm{~s}$ and annealing/extension at $60^{\circ}$ for $10 \mathrm{~min}$. Data from real-time assays were calculated using the v1.7 sequence detection software from PE Biosystems (Foster City, CA). Relative expression of studied gene mRNA was calculated using the comparative $\mathrm{Ct}$ method. All values were normalized to beta actin which was used as a control housekeeping gene and reported as fold change over background levels detected in the diseased groups.

\section{Histological estimation:}

Specimens taken and sectioning:

After scarification, pancreatic tissues were immediately dissected and paraffin blocks were prepared in department of histology. Sections of 5 m thickness were subjected to:

A- Hematoxylin \& eosin (H \& E). 
B- Immunohistochemical staining for antiinsulin: The staining was done according to Bancroft and Cook using a mouse monoclonal antibody (Insulin Ab-6 (INS04 + INS05) (Lab Vision Corporation Laboratories, CA 94539, USA, catalogue number MS-1379-P) [21]. Sections were incubated in hydrogen peroxide for 30 minutes then rinsed in PBS. Each specimen was prepared according to manufacturer's instruction. Anti-insulin immunopositivity appeared as cytoplasmic brown deposits in the 3 -cells. Non-specific background elimination step was omitted.

Table (1): The primer sequence of studied gene.

\begin{tabular}{ll}
\hline & Primer sequence \\
\hline Pax4 & Forward primer: 5'--CAGCAGCATGGACCAGCTTGG-3 \\
& Reverse primer: 5'-CTCCTGTAATGCCCGCAGGAC-3 \\
Arx & Forward primer: 5'--GGCCGGAGTGCAAGAGTAAAT-3 \\
& Reverse primer: 5'-TGCATGGCTTTTCCTGGTCA-3 \\
Ngn3 & Forward primer: 5'-CTGCGCATAGCGGACCACAGCTTC-3 \\
& Reverse primer: 5'-CTTCACAACTCTGAGAACACCAG3' \\
Bcl-xl & Forward primer: 5'-CAT GCC AAG AGG GAA ACA CCA GAA-3 \\
& Reverse primer: 5'-GTG CTT TGC ATT CTT GGA TGA GGG-3' \\
NF- אB & Forward primer: 5'-CATTGAGGTGTATTTCACGG-3 \\
& Reverse primer: 5'-GGCAAGTGGCCATTGTGTTC-3 \\
Beta actin & Forward primer: 5'-TGTTTGAGACCTTCAACACC-3' \\
& Reverse primer: 5'-CGCTCATTGCCGATAGTGAT-3' \\
\hline
\end{tabular}

\section{Histomorphometric study:}

Data were obtained using "Leica Qwin 500 C" Image Analyzer Computer System Ltd. (Cambridge, England). Mean area percent of anti-insulin immunopositive cells were measured in all immunostained pancreas sections. From each section 10 non overlapping fields were examined using an objective lens X10 (=total magnification X100) and the mean value for each slide was obtained.

\section{Statistical methods:}

Data were coded and entered using the statistical package SPSS Version 24. Then values were summarized using mean and standard deviation. Comparisons between groups were done using analysis of variance (ANOVA) with multiple comparisons post hoc test [22]. $p$-values less than 0.05 were considered as statistically significant.

\section{Results}

Injecting STZ to pregnant females at a dose of 40mg/kg successfully induced GDM:

Before injecting STZ, FBG was 92.33 (4.46) in Group I (C), 90 (6.93) in Groups II (pregnantSTZ), 88.83 (4.17) in Group III [pregnant-STZVit D (P)] and 91 (2.83) in Group IV [pregnantSTZ-Vit D $(\mathrm{P}+\mathrm{L})]$. However, three days after STZ injection the mean values of FBG were 91 (6.62), 204.66 (5.99), 189.66 (7.92) and 192.5
(5.92) for Group I, II, III and IV respectively assuring induction of GDM. FBS was also recorded just before delivery thus pronouncing continuation of GDM, mean values were 91.5 (2.43), 203.33 (5.57), 181.16 (5.81) and 184 (5.76) for Group I, II, III and IV respectively.

Changes in offspring's blood glucose levels ( $\mathrm{mg} / \mathrm{dl}$ ) before and after HFD in response to IGTT:

Data was measured at 3 and 5 weeks of postnatal life respectively, before intake of HFD, FBG levels showed significant increase in group II compared to control group and no statistically difference between Group III and IV compared to control and with each other, FBG of both Groups (III and IV) are significantly lower than that of Group II. However after 30 and 120 of IPGTT data of all groups showed significant increase compared to control, thus it could reflect functional deterioration in $\beta$ cells with partial protection in Group IV [pregnantSTZ-Vit D $(\mathrm{P}+\mathrm{L})$ ] documented by significant decrease in blood glucose levels compared to both Group II and III. Adding burden of HFD for 2 weeks resulted in accelerated 3 -cell dysfunction reflected by increased $\mathrm{FBG}$ inoffsprings born to all STZ-injected mothers. Failure of compensation was more clear in data of offsprings born to mothers included in Group II, FBG 170.8571 (2.035401), after 30min of IPGTT 246.8571 (3.804759) and after 120 of IPGTT 224.2857 (3.728909) Fig. (1). 
Intrapertonial Glucose Tolerance

Test before intake of HFD

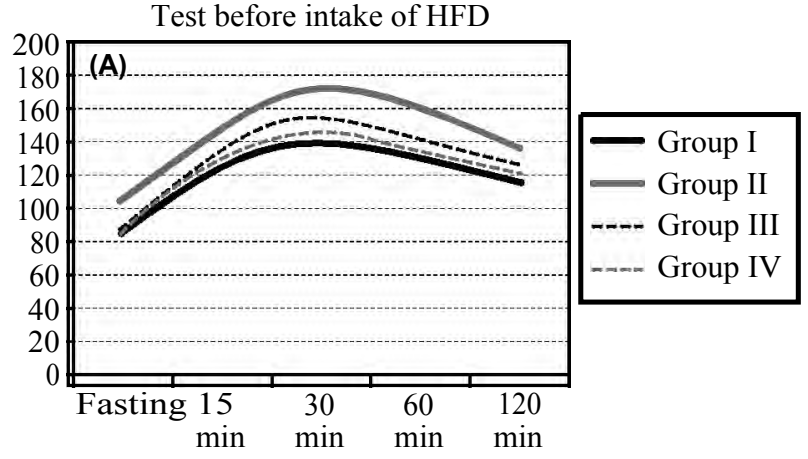

Before HFD

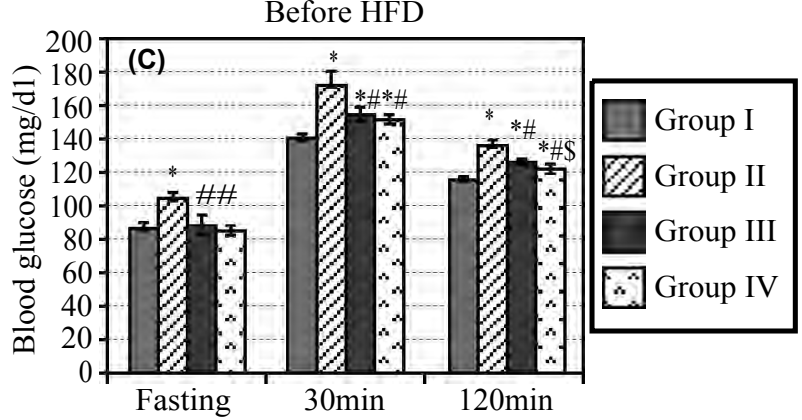

Intrapertonial Glucose Tolerance

Test ( 2 weeks after $45 \%$ HFD)
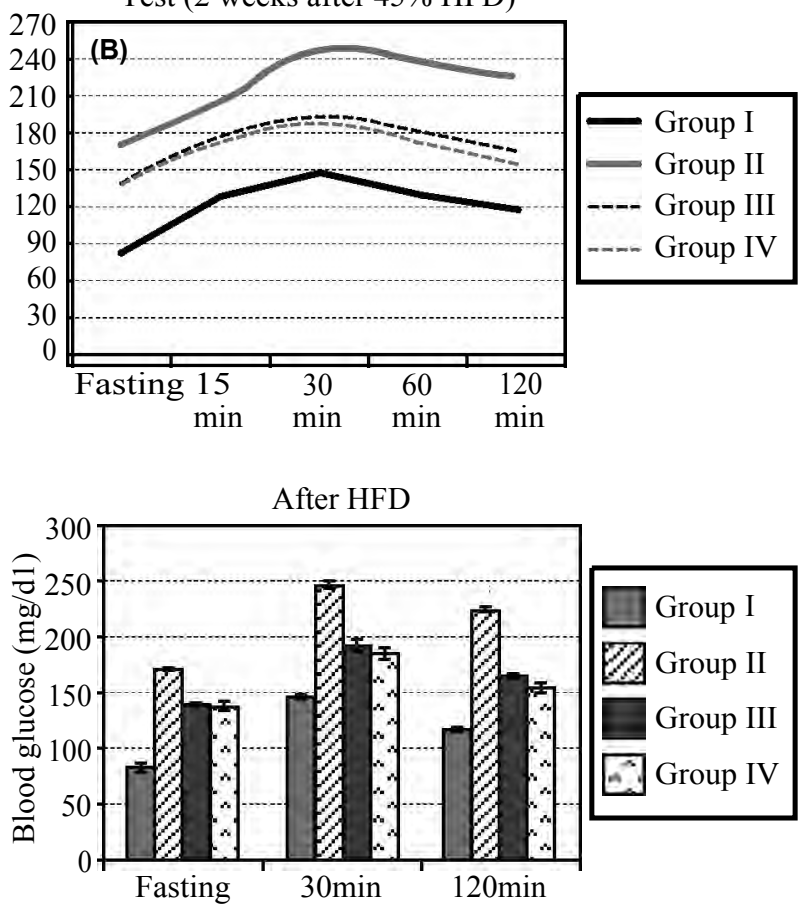

Fig. (1): "A,B" Timeline changes of blood glucose levels of offsprings in different groups before and 2 weeks after intake of $45 \%$ HFD, "C,D" Shows data presented by mean \pm SD of fasting blood glucose levels, 30 minutes and 120 minutes after IPGTT.

$*: p<0.05$, significantly different from the respective control group.

$\#: p<0.05$, significantly compared to Group II (pregnant-STZ).

$\$: p<0.05$, significantly different from Group III (pregnant-STZ-Vit D (P)).

Changes in mean values of insulin levels $(\mathrm{ng} / \mathrm{ml})$ and area\% of $\beta$-cells before and after HFD:

Data of insulin levels reflects limited $\beta$-cells functional capacity detected before the intake of fat regimen of diet that coincided with the age of 3 weeks of postnatal life and continued after intake

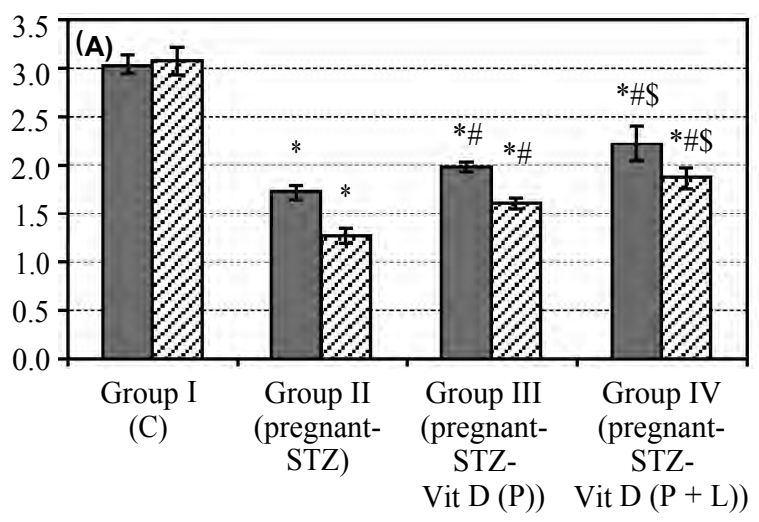

Insulin before HFD $(\mathrm{ng} / \mathrm{ml}) \quad Q$ Insulin after HFD $(\mathrm{ng} / \mathrm{ml})$
HFD. In addition, increased area $\%$ of anti-insulin antibodies in Group IV compared to both Group II and III at the age of 3 weeks (the time of weaning) may indicate the contributing effect of Vitamin D supplementation during dynamic the period of $\beta$ cells development Fig. (2).

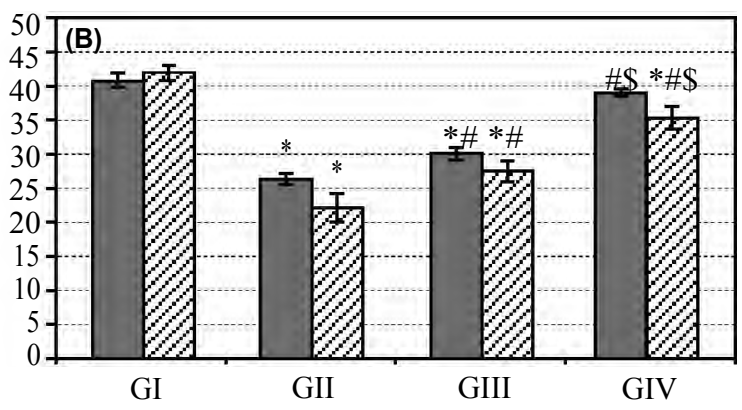

Before HFD

After HFD

Fig. (2): “A” Represents mean values of insulin levels and "B” Shows quantitative analysis of anti-insulin antibody area \%. 
Effect of maternal supplementation with Vitamin $D$ on offspring's relative gene expression of Pax4, Arx and Ngn3 before and changes in Pax4 two weeks after HFD:

Ngn3 was up-regulated significantly in Group IV compared to all other groups, in addition its downstream Pax4 gene showed significant decrease before and even after the intake of HFD in all offsprings born to diabetics compared to control Fig. (3).

Changes in serum values of TG $(\mathrm{mg} / \mathrm{dl})$, cholesterol $(\mathrm{mg} / \mathrm{dl}), M D A(\mathrm{mmol} / \mathrm{l})$, relative expression ofNF-кB and BCL-xl before and HFD in all studied groups:

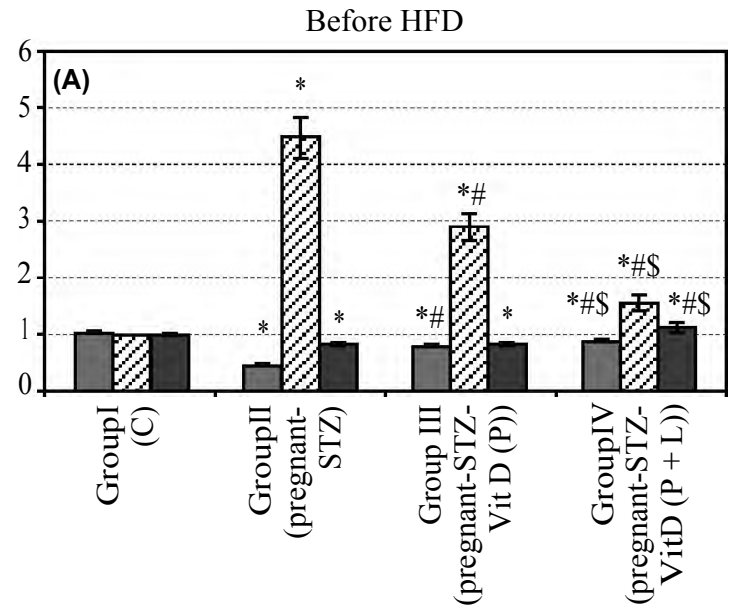

$\square \operatorname{Pax} 4$ Arx $\quad$ Ngn3

Vitamin D could decrease serum levels of TG and cholesterol. With its anti-inflammatory/antioxidant effects, and it could regulate NF- $к B$ induced functional disruption of (3-cells therefore protects pancreatic tissues from apoptosis via significantly increased relative gene expression of BCL-xl (Table 2). Even more, in all pups born to diabetic mothers "in Groups II, III and IV" the results documented significantly higher values of $\mathrm{NF}-\kappa \mathrm{B}$ than control group, however it was significantly lower in (pregnant-STZ-Vit D (P) and IV [pregnant-STZ-Vit D (P + L)] groups than (pregnant-STZ) which may indicates the anti-apoptotic antioxidant effect of Vitamin D.

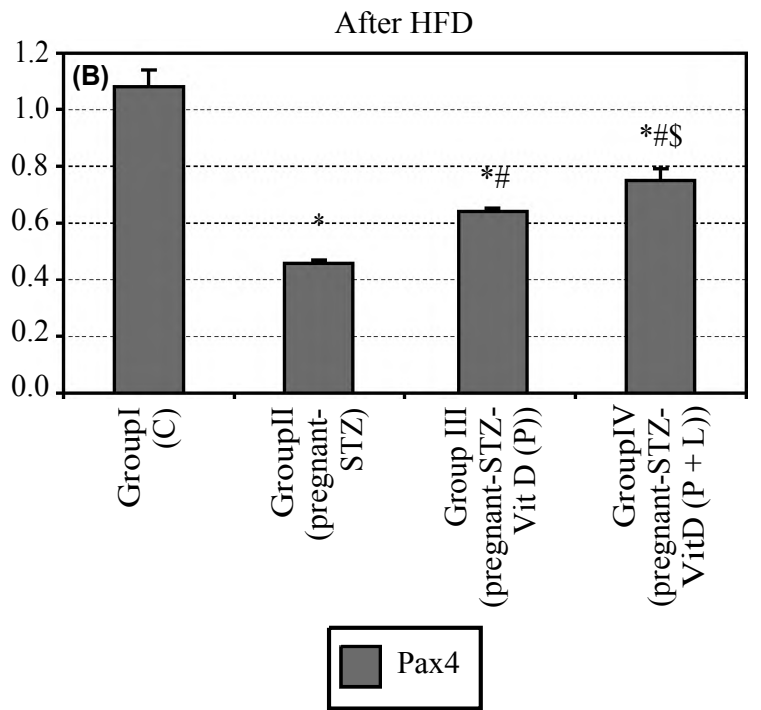

Fig. (3): "A" Represent values of relative gene expression of Pax4, Arx and Ngn3 before HFD and "B" Mean values of Pax4 after HFD in all studied groups.

Data presented by mean \pm SD

* : $p<0.05$, significantly different from respective control group.

\# : $p<0.05$, significantly different from respective (pregnant-STZ) group.

$\$: p<0.05$, significantly different from respective (pregnant-STZ-Vit D (P)).

(a) $: p<0.05$, significantly different in each group before from after HFD.

Table (2): Modulating effects of Vitamin D during pregnancy and lactationin offsprings born to STZ-induced diabetic mothers.

\begin{tabular}{|c|c|c|c|c|}
\hline & $\begin{array}{l}\text { Group I } \\
\text { (C) }\end{array}$ & $\begin{array}{c}\text { Group II } \\
\text { (pregnant-STZ) }\end{array}$ & $\begin{array}{c}\text { Group III } \\
\text { (pregnant-STZ- } \\
\text { Vit D (P)) }\end{array}$ & $\begin{array}{c}\text { Group IV } \\
\text { (pregnant-STZ- } \\
\text { Vit D }(\mathrm{P}+\mathrm{L}))\end{array}$ \\
\hline TG before HFD (mg/dl) & $69.00(3.11)$ & $106.92(3.93)^{*}$ & $87.70(1.92) * * *$ & $70.40(3.85) * *, * * *$ \\
\hline Cholesterol before HFD (mg/dl) & $152.00(7.54)$ & $200.83(5.60)^{*}$ & $179.17(5.49) * * *$ & $167.33(3.98) *, * *, * * *$ \\
\hline TG after HFD (mg/dl) & $70.30(3.65)$ & $135.45(2.30)^{*}$ & $112.50(3.51) * * *$ & $97.13(2.96) * * *, * * *$ \\
\hline Cholesterol after HFD (mg/dl) & $156.00(6.81)$ & $302.33(9.65)^{*}$ & $230.50(8.04) * * * *$ & $207.67(5.68) *, * *, * * *$ \\
\hline MDA before HFD $(\mathrm{mmol} / \mathrm{l})$ & $6.72(0.29)$ & $87.02(3.34)^{*}$ & $31.32(1.59) * * *$ & $22.42(1.92) * * * * * *$ \\
\hline MDA after HFD (mmol/1) & $7.33(0.54)$ & $119.15(1.76)^{*}$ & $70.53(1.18) * * *$ & $48.58(0.93) * * *, * * *$ \\
\hline NF-кB before HFD (relative expression) & $1.00(0.01)$ & $8.67(0.64)^{*}$ & $6.60(0.35)^{*}, * *$ & $4.68(0.32)^{*}, * *, * * *$ \\
\hline BCL-xl before HFD (relative expression) & $1.00(0.01)$ & $0.41(0.04)^{*}$ & $0.69(0.04) *, * *$ & $0.89(0.04) *, * *, * * *$ \\
\hline NF-кB after HFD (relative expression) & $2.05(0.03)$ & $15.00(1.21)^{*}$ & $10.11(0.39) *, * *$ & $7.57(0.44) *, * * * * *$ \\
\hline BCL-xl after HFD (relative expression) & $0.85(0.03)$ & $0.13(0.01)^{*}$ & $0.57(0.05) * * *$ & $0.70(0.01) *, * *, * * *$ \\
\hline
\end{tabular}

Values are presented as mean \pm SD.

$*, * *$ and $* * *$ : Statistically significant compared to corresponding value in Group I, II and III respectively $(p<0.05)$ 


\section{Histological results:}

Haematoxylin and eosin stained sections and insulin immune-reactivity in all studied groups before HFD intake:

Degenerative changes and decreased immunereactivity of anti-insulin antibody were detected in pancreatic sections of pups born to diabetics, however these changes was attenuated in pups born to mothers supplemented with Vitamin D. In Group IV continuation of Vitamin D intake till the time of weaning could enhance insulin immune- reactivity that appeared presumably from pancreatic ducts Fig. (4).

Haematoxylin and eosin stained sections and insulin immune-reactivity in all studied groups after HFD intake:

Intake of HFD for two weeks in early adult file (just after weaning) induced marked degenerative changes in islets that were significantly attenuated in pups that mothers were supplied with Vitamin D during pregnancy and lactation Fig. (5).
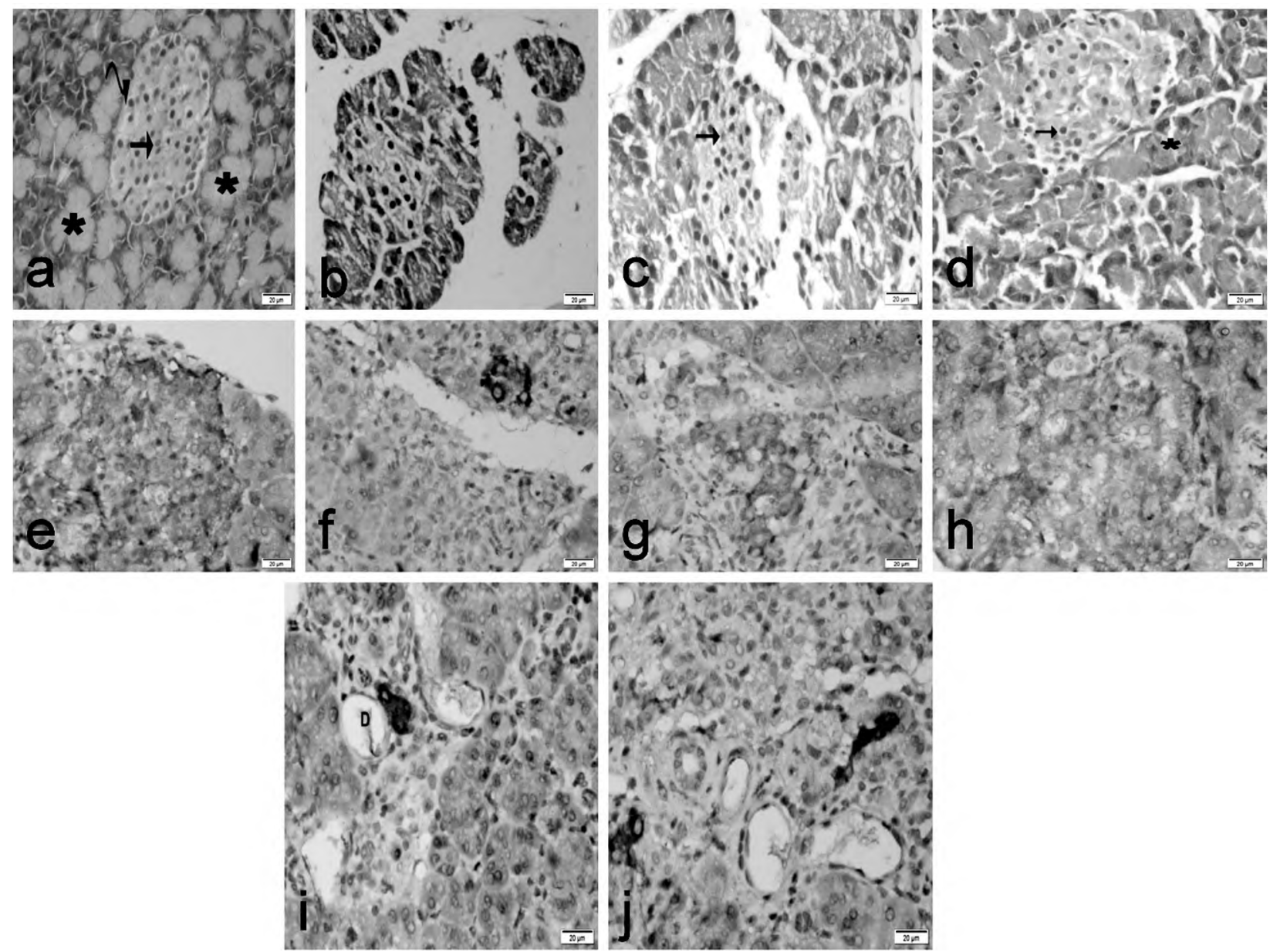

Fig. (4): Photomicrographs of sections in the pancreas of rats (before HFD) (H \& E X400; anti-insulin X400) from: (A): Control group showing the islets with presence of peripheral alpha-cells exhibiting smaller and darker nuclei (curved arrow) and 3 -cells with lighter and larger nuclei (arrow). The surrounding pancreatic acini show characteristic basal basophilia and apical acidophilia (stars), (B): Group II showing irregular outline and severe degenerative changes of pancreatic islets, especially in the center. Destructed cells showed dark acidophilic cytoplasm. Not the destructed acini with pyknoticacinar cells, (C): Group III showing irregular outline with decrease in the degenerative changes of pancreatic islets. Some cells have deeply stained cytoplasm with fragmented nuclei (arrow), (D): Group IV showing marked improvement, thus the islets appear near to the control with gain of their regular outline. Few degranulated cells are seen (arrow). The acini are intact (star), (E): Control group showing revealed dense brown cytoplasmic immunoreactivity that was detected in most of pancreatic islets' cells, $(\mathrm{F})$ : Group II showing markedly decreased immunoreactivity in the islet of Langerhans, (G): Group III showing moderate decrease in positively immunostained $\beta$-cells, (H): Group IV showing increase in positively immunostained $\beta$-cells, (I): Group IV showing insulin positive cells appeared as budding from the pancreatic duct (D), (J): Group IV represents tiny scattered clusters of insulin positive cells between pancreatic acini. 

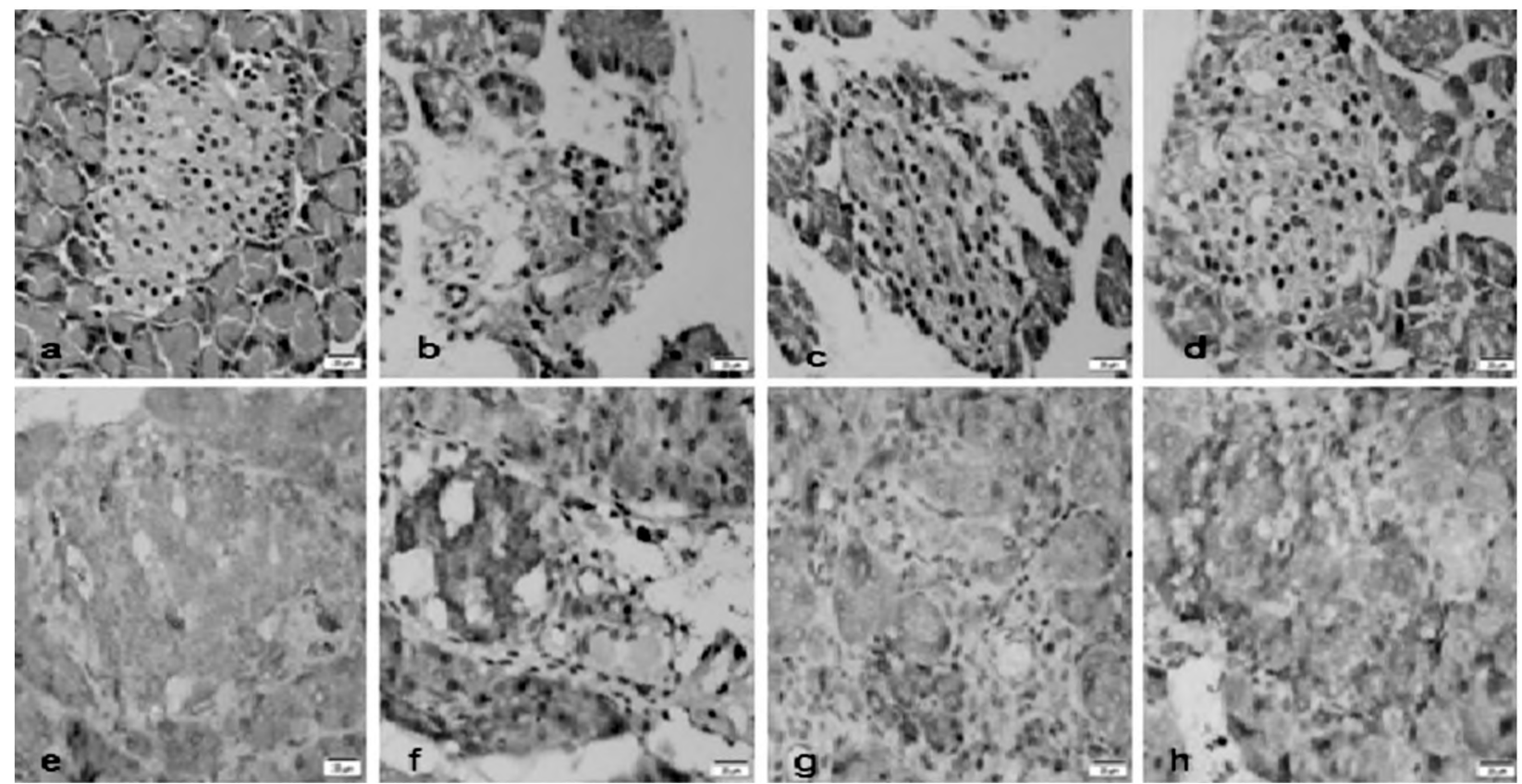

Fig. (5): Photomicrographs of sections in the Pancreas of rats (after HFD) (H \& E X400; anti-isulin X400) from: (A): Control group showing normal isltes and acini, (B): Group II showing marked irregularity of islets outline with severe degenerative changes. Esinophilic material with few inflammatory cells is seen suggesting insulinitis. Large vacuolations observed in between degenerated islets cells and acini, (C): Group III showing persistent degenerative changes of islets, (D): Group IV minimal degenerative changes of islets were seen with preserved general structure of the pancreas, (E): Control group showing dense positive immunoreaction in $\beta$-cells, (F): Group II showing marked decrease in positively immunostained $\beta$-cells. Note the multiple large vacuoles between islets cells, $(\mathrm{G})$ : Group III showing moderate decrease in positively immunostained $\beta$-cells, $(\mathrm{H})$ : group IV showing increased immunoreaction in $\beta$-cells.

\section{Discussion}

Increased maternal-to-fetal glucose supply as consequence of GDM has multiple detrimental effect during fetal development including high risk of macrosomia, preterm and 'gestational reprogramming' of pancreatic tissues [23]. Badawoud in 2006 studied the effect of GDM on $\beta$-cell of newly born pups at one and four days of their postnatal life, results documented hypertrophy and proliferation of fetal $\beta$-cell that was secondary to the state of hyperglycemia during pregnancy [24]

The authors of Pima Indian studies in 2000 and 2006 confirmed implementation of GDM on increased risk obesity and type IIDM among offsprings born to diabetic mothers [25]. In our study, the impact of STZ-induced GDM on $\beta$-cell function and morphology of pups in late neonatal period caused deterioration in results of IPGTT and decreased insulin levels before and 2 weeks after intake of $45 \%$ HFD. Decreased area $\%$ of $\beta$-cells in pups born to mothers in STZ-pregnant group emphasized the existence of altered fetal pancreatic $\beta$-cells morphology that could affect their function.

In agreement with [26] who examined insulin secretion in ex vivo study on islets isolated from offspring of STZ-diabetic mothers and reported degranulationand reduced number of fetal beta cells. Malcolm et al., (2006) recorded impaired glucose tolerance and obesity among children born to diabetics [27]

The presence of critical period during organ development especially pancreas that could induce functional and structural rearrangement is a concept supported previously. $\beta$-cell replication continues during neonatal period then declines after weaning [28]. Thus, we investigated genetic changes in neonatal pancreatic tissues during lactation and at time of weaning that was the age of 3 weeks postnatal life.

The state of chronic hyperglycemia could alter PDX-1 (pancreatic and duodenal homeobox-1) ability to bind to insulin promoter gene consequently [29] result in decreased gene expression at mRNA level. PDX1 gene, a master gene for early pancreatic development [30], is an upstream regulator of $\mathrm{Ngn} 3$, the latter plays a critical role in the formation of pancreatic endocrine precursors [31]. Pax4 and Arx are the down-streams of Ngn3, even more the co-expression of insulin and glucagon from Ngn3progenitor cells was confirmed [32], indicating that Pax4 and Arx exert opposing actions in development and maturation of endocrine precursors. 
Indeed, these two factors were shown to inhibit the expression of each other [33]. Thus could explain the increased levels of Arx relative gene expression in Group II, III and IV together with decreased Pax4 in the same groups.

Therefore, the decreased Pax 4 relative gene expression may be due to shift of pancreatic progenitor cells towards glucagon secreting cells rather than insulin secreting cells, as Pax4 expression is restricted to (3-cell development then later to adult mature one [34]. In our results, Pax4 expression was significantly increased in offspring's born to mothers in Group III and IV compared to results in Groups II with the presence of statistically increased values in Group IV compared to III, that was associated with increased area $\%$ of anti-insulin antibody and plasma insulin levels in the same group, which was reflected on euglycemic control of IPGTT in Group IV compared to Group I.

The predicted timing of neogenesis is two, the first one is immediately after birth and the second occurs 2-3 weeks later. In our study, the anti-insulin antibody localized the presence of neogenesis only in Group IV "the group of continues supplementation of Vitamin D during lactation". The appearance of insulin immune-reactivity within the ductal epithelium indicates budding from pancreatic ducts. Bonner-Weir et al., (2004) also reported that the epithelium of pancreatic duct could serve a pool for islet progenitor cells after birth till adulthood [35]. Appearance of islets budding from the ducts over the first month after birth and just at time of weaning confirms the existence and continuation of neogenesis till weaning. Ngn3, the marker of induced trans-differentiation of pancreatic progenitor cells from ducts to islet cells [36], was increased Ngn3 neonatal pancreatic tissues of pups born to mothers of Group IV. Thus Vitamin D could control plasticity of pancreatic duct epithelium.

Malondialdehyde was observed to be increased in serum samples of offsprings born Group II before intake of HFD together with increased FBG. Increased ROS could alter function and survival of the beta cell through dys-regulated gene expression and apoptosis [37].

Activation of NF- $\kappa B$ is a crucial step for various cytokine-induced ( 3 -cell dysfunction, thus leads to stimulation of inducible Nitric Oxide (NO) synthase and subsequent NO production. The latter could decrease expression of transcription factors controlling (3-cell function and differentiation) [38] Pieper et al., (2004) confirmed nuclear localization and increased binding activity of NF- $\mathrm{\kappa B}$ within islets of diabetic-prone BB rats and recent-onset hyperglycemic rats (within 48h) [39].

Nazari et al., (2017) reported that streptozotocin-induced maternal hyperglycemia could disturb (3-cells growth during early postnatal period and increases the prevalence of diabetes among offspring in adult life, authors related the increased (3-cell apoptosis to IL-1 (3-mediated activation of NF- $\kappa$ B. In this context, decreased area $\%$ of antiinsulin antibody in pancreatic sections of offsprings born to diabetics may be also related to increased$\mathrm{NF}-\kappa \mathrm{B}$ relative gene expression in their pancreatic tissues [16]. Pro-survival factor, BCL-xl, was decreased in IV, however this decrease wasn't significant compared to control, suggesting that continues intake of Vitamin D till the time of weaning could modulate the burst of (3-cell apoptosis during this period. Moreover, reduced expression levels of BCL-xl could increase (3-cell apoptosis leading eventually to in insufficient (3-cell mass and progressive glucose intolerance [40]

Maternal 25(OH) D freely crosses human placenta as well as that of rodents [41]. According to UK Chief Medical Officers recommendations (2012), the chosen dose of Vitamin D given to pregnant mothers in the present work was 400 IU/day. However, the dose during lactation was 4000IU/day, therefor it could raise neonatal serum $25(\mathrm{OH}) \mathrm{D}$ concentrations to sufficient range.

Vitamin D up-regulates the inhibitor of NF- $к B$ (ІкВ- $\alpha$ ) by increasing ІкB- $\alpha$ stability and decreasing phosphorylation. Increased I кB- $\alpha$ stability causes reduced-nuclear translocation of p65/p50 and NF- $\kappa \mathrm{B}$ activity. In view of this, Vitamin D could exert its anti-inflammatory effects [42]. In addition, Baker et al., (2011) reported significant amelioration of insulin resistance and glucose metabolism in patients with impaired glucose tolerance following treatment with salicylates which could inhibit NF- $\kappa B$ activation [43].

In the present work, intake of HFD for two weeks could increase NF- $\kappa B$ relative gene expression in all groups, decreased Pax4 gene expression and impaired IPGTT in Group II thus accelerated the development of DM among offspring born to this group. This highlighted the effects of HFD intake as one of causative factors of rapid deterioration of $(3$-cell function in our study.

Degeneration and vacuolizations observed in pancreatic acinar and islet cells in rats fed HFD was in accordance with study done by Gulen et al., (2015) [44] 
Accumulated fat inside (3-cells together with elevated Free Fatty Acid (FFA) level in blood may lead to (3-cell apoptosis secondary to enhanced biosynthesis of ROS, local up-regulated NF- $\mathrm{KB}$ protein levels, increased NO [45]. The associated hyperglycemia, hyperlipidemia and consequent lipotoxicity are key mediators of islet damage. In addition, increased intra-islet lipid accumulation impairs glucose-stimulated insulin secretion promoting islet inflammation and progressive $(3$-cell damage leading to apoptosis and finally islet failure [9].

Genetically-induced Bcl-xL deficient islets in rats have a normal appearance in adulthood. However, Bcl-xL deficient (3-cells were more sensitive to low dose STZ as well as other cytotoxic drugs [46]. Therefore in our study, decreased levels of BCL-xl gene expression during early postnatal life may be a contributing factor for increased sensitivity to HFD intake. With continues supplementation of vitamin D till lactation in Group IV, the nursing offsprings were protected from development of DM compared to those born to Group II and III. Taken together, Vitamin D is required to improve insulin secretion and to prevent beta-cell dysfunction.

In conclusion, intake of Vitamin D during pregnancy and lactation could support pancreatic (3cell neogenesis in offsprings born to STZ-induced diabetic mothers and minimized the effect of HFDintake via down-regulation of pancreatic NK- $\mathrm{KB}$ and increasing BCL-xl gene expression. Further investigations are recommended to study the effect of Vitamin D on (3-cell survival.

\section{Conflict of interest:}

All authors declare no conflict; the present study was conducted without any financial or commercial relationship between authors.

\section{Acknowledgement:}

We express our thanks to the animal house of our NRC for providing this project with animals and continuous care of them throughout the duration of the study helping completion of this work.

\section{References}

1- FOWDEN A.L. and HILL D.J.: Intra-uterine programming of the endocrine pancreas. The British Medical Bulletin, 60: 123-42, 2001.

2- BOLOKER J., GERTZ S.J. and SIMMONS R.A.: Gestational diabetes leads to the development of diabetes in adulthood in the rat. Diabetes, 51 (5): 1499-506, 2002.

3- AERTS L., HOLEMANS K. and VAN ASSCHE F.A.: Impaired insulin response and action in offspring of severely diabetes rats. In: Shafrir E, editor. Frontiers in Diabetes Research. Lessons from Animal Diabetes III. Cambridgeshire, UK: Smith-Gordon, 561-6, 1990.

4- LUCAS A.: Programming by early nutrition: An experimental approach. J. Nutr., 128 (2): 401-6, 1998.

5- HOLEMANS K., AERTS L. and VAN ASSCHE F.A. Lifetime consequences of abnormal fetal pancreatic development. The Journal of Physiology, 547 (Pt 1): 11-20, 2003.

6- VAN ASSCHE F.A., HOLEMANS K. and AERTS L.: Long-term consequences for offspring of diabetes during pregnancy. British Medical Bulletin, 60: 173-82, 2001.

7- MOTA M., BANINI B.A., CAZANAVE S.C. and SANYAL A.J.: Molecular Mechanisms of Lipotoxicity and Glucotoxicity in Nonalcoholic Fatty Liver Disease. Metabolism: Clinical and experimental, 65 (8): 1049-61. doi:10.1016/j.metabol.2016.02.014, 2016.

8- DeFRONZO R.A.: Insulin resistance, lipotoxicity, type 2 diabetes and atherosclerosis: The missing links. The Claude Bernard Lecture 2009. Diabetologia, 53 (7): 127087. doi:10.1007/s00125-010-1684-1, 2010.

9- DEL PRATO S.: Role of glucotoxicity and lipotoxicity in the pathophysiology of Type 2 diabetes mellitus and emerging treatment strategies. Diabet. Med., 26: 118592, 2009.

10- LEUNG P.S.: The Potential Protective Action of Vitamin D in Hepatic Insulin Resistance and Pancreatic Islet Dysfunction in Type 2 Diabetes Mellitus. Nutrients, 8 (3): 147, 2016.

11- KORDOWICH S., COLLOMBAT P., MANSOURI A. and SERUP P.: Arx and Nkx2.2 compound deciency redirects pancreatic alpha-and beta-cell differentiation to a somatostatin/ghrelin co-expressing cell lineage. B.M.C. Developmental Biology, Bio. Med. Central., 11 (1): 52, 2011.

12- COURTNEY M., GJERNES E., DRUELLE N., RAVAUD C., VIEIRA A., BEN-OTHMAN N., PFEIFER A., AVOLIO F., LEUCKX G., LACAS-GERVAIS S., BURELVANDENBOS F., AMBROSETTI D., HECKSHER SORENSEN J., RAVASSARD P., HEIMBERG H., MANSOURI A. and COLLOMBAT P.: The Inactivation of Arx in Pancreatic $\alpha$-Cells Triggers Their Neogenesis and Conversion into Functional (3-Like Cells. PLoS Genet, 9 (10): e1003934, 2013.

13- BOUWENS L. and KLOPPEL G.: Islet cell neogenesis in the pancreas. Virchows Arch., 427: 553-60, 1996.

14- RASTEGAR S., SOLTANI S., ROOHIPOOR A. and EBRAHIMI E.: Study of plants with D-chiro-inositol and its derivatives on diabetes. Int. J. Pharmacogn, 4: 43-53, 2017.

15- MITRI J. and PITTAS A.G.: Vitamin D and diabetes. Endocrinology and Metabolism Clinics of North America 43 (1): 205-32, 2014

16- NAZARI Z., NABIUNI M., GHAFFARI S., SAEIDI M., SHAHRIYARI A. and JAFARGOLALIPOUR M.: Gestational Diabetes Induces Pancreatic Beta-Cells Apoptosis in Adult Rat Offspring. Int. J. Morphol., 35 (1): 16-20, 2017 
17- NAGESHU S., KRISHNA K., KRISHNA L., BHAT S., SUMA R. and REDDY S.: A study of prevalence of Vitamin D deficiency among pregnant women and its impact on feto maternal outcome. Int. J. Reprod. Contracept. Obstet. Gynecol., 5 (4): 1174-80, 2016.

18- PAGET G.E. and BARNES J.M.: Toxicity tests. In: Laurence DR, Bacharach AL (ed.) Evaluation of drug activities. Pharmacometrics (p 161). London: Academic Press, 1964.

19- HOLLIS B.W. and WAGNER C.L.: Vitamin D requirements during lactation: high-dose maternal supplementation as therapy to prevent hypovitaminosis $\mathrm{D}$ for both the mother and the nursing infant. Am. J. Clin. Nutr., 80 (suppl): 1752S-8S, 2004.

20- WILLS E.D.: Evaluation of lipid peroxidation in lipids and biological membranes. In: Snell K, Mullock B, eds. Biochemical toxicology: A practical approach. London: Oxford, 1987.

21- BANCROFT J. and COOK C.: Immunocytochemistry In: Manual of hiştological techniques and their diagnostic applications. ed. Churchill Livingstone; Edinburgh, London, Madrid, Melbourne, New York and Tokyo, 263$325,2001$.

22- CHAN Y.H.: Biostatistics 102: Quantitative DataParametric \& Non-parametric Tests. Singapore Med. J., 44 (8): 391-6, 2003.

23- GARCIA-VARGAS L., ADDISON S.S., NISTALA R., KURUKULASURIYA D. and SOWERS J.R.: Gestational Diabetes and the Offspring: Implications in the Development of the Cardiorenal Metabolic Syndrome in Offspring. Cardiorenal Medicine, 2 (2): 134-42, 2012.

24- BADAWOUD M.H.: The effect of maternal diabetes on pancreatic islets in newborn rats: A quantitative and immunocytochemical study. Folia Morphol (Warsz), 65 (2): 152-6, 2006

25- FRANKS P.W., LOOKER H.C., KOBES S., TOUGER L., TATARANNI P.A., HANSON R.L. and KNOWLER W.C.: Gestational glucose tolerance and risk of type 2 diabetes in young Pima Indian offspring. Diabetes, 55: 460-5, 2006.

26- HAN J., XU J., LONG S., EPSTEIN N. and LIU Q.: Rat maternal diabetes impairs pancreatic 3 -cell function in the offspring. Am. J. Physiol. Endocrinol. Metab., 293 (1): 228-36, 2007.

27- MALCOLM J.C.1., LAWSON M.L., GABOURY I., LOUGH G. and KEELY E.: Glucose tolerance of offspring of mother with gestational diabetes mellitus in a low-risk population. Diabet. Med., 23 (5): 565-70, 2006.

28- AGUAYO-MAZZUCATO C., SANCHEZ-SOTO C., GODINEZ-PUIG V., GUTIÉRREZ-OSPINA G. and HIRIART M.: Restructuring of pancreatic islets and insulin secretion in a postnatal critical window. PLoS ONE, 1 (1, article e35), 2006.

29- FUJIMOTO K. and POLONSKY K.S.: Pdx 1 and other factors that regulate pancreatic (3-cell survival. Diabetes, obesity \& metabolism, 11 (Suppl 4): 30-7, 2009.

30- OLIVER-KRASINSKI J.M., KASNER M.T., YANG J., CRUTCHLOW M.F., RUSTGI A.K., KAESTNER K.H. and STOFFERS D.A.: The diabetes gene Pdx1 regulates the transcriptional network of pancreatic endocrine progenitor cells in mice. The Journal of Clinical Investigation, 119 (7): 1888-98, 2009.

31- LIANG D., GUO Y., SUN M., DING Y., WANG N., YUAN L. and DE W.: Streptozotocin-induced expression of Ngn3 and Pax 4 in neonatal rat pancreatic $\alpha$-cells. World J. Gastroenterol., 17 (23): 2812-20, 2011.

32- REZANIA A., RIEDEL M.J., WIDEMAN R.D., KARANU F., AO Z., WARNOCK G.L. and KIEFFER T.J.: Production of Functional Glucagon-Secreting $\alpha$-Cells From Human Embryonic Stem Cells. Diabetes, 60 (1): 239-47, 2011.

33- COLLOMBAT P., HECKSHER-SORENSEN J., BROCCOLI V., KRULL J., PONTE I., MUNDIGER T., SMITH J., GRUSS P., SERUP P. and MANSOURI A.: The simultaneous loss of Arx and Pax4 genes promotes a somatostatin-producing cell fate specification at the expense of the $\alpha$-and ( 3 -cell lineages in the mouse endocrine pancreas. Development, 132: 2969-80, 2005.

34- HE H., LORENZO I., BRUN T., MORENO J., AEBERHARD D., ORTEGA V. and HERRERA L.: In vivo conditional Pax4 overexpression in mature islet (3-cells prevents stress-induced hyperglycemia in mice. Diabetes, 60 (6): 1705-15, 2011.

35- BONNER-WEIR S., TOSCHI E., INADA A., REITZ P., FONSECA S.Y., AYE T. and SHARMA A.: The pancreatic ductal epithelium serves as a potential pool of progenitor cells. Ped. Diabetes, 5: 15-22, 2004.

36- SWALES N., MARTENS A., BONNÉ S., HEREMANS Y., BORUP R., VAN De CASTEELE M. and FERRER J.: Plasticity of adult human pancreatic duct cells by neurogenin3-mediated reprogramming. PLoS One, 7 (5): e37055. doi: 10.1371, 2012.

37- GERBER P.A. and RUTTER G.A.: The Role of Oxidative Stress and Hypoxia in Pancreatic Beta-Cell Dysfunction in Diabetes Mellitus. Antioxidants \& Redox Signaling, 26 (10): 501-18, 2017.

38- FU Z., GILBERT E.R. and LIU D.: Regulation of Insulin Synthesis and Secretion and Pancreatic Beta-Cell Dysfunction in Diabetes. Current Diabetes Reviews, 9 (1): 25-53, 2013.

39- PIEPER C.M., ROZA A.M., HENDERSON J.D. Jr., ZHU Y.R. and LAI C.S.: Spatial distribution and temporal onset of NF- $\mathrm{KB}$ activation and inducible nitric oxide synthase within pancreatic islets in the pre-diabetic stage of genetic, diabetic-prone BB rats: Attenuation by drug intervention decreases inflammatory cell infiltration and incidence of diabetes. Inflamm. Res., 53 (1): 22-30, 2004.

40- ACKERMANN A.M. and GANNON M.: Molecular regulation of pancreatic (3-cell mass development, maintenance, and expansion. J. Mol. Endocrinol., 38: 193-206, 2007.

41- KOVACS C.S.: Vitamin D in pregnancy and lactation: Maternal, fetal, and neonatal outcomes from human and animal studies. American Journal of Clinical Nutrition, 88: 520S-528S, 2008.

42- CHAGAS C.E.A., BORGES M.C., MARTINI L.A. and ROGERO M.M.: Focus on Vitamin D, Inflammation and Type 2 Diabetes. Nutrients, 4 (1): 52-67, 2012. 
43- BAKER R.G., HAYDEN M.S. and GHOSH S.: NF- kB, inflammation and metabolic disease. Cell Metabolism, 13 (1): 11-22, 2011.

44- GULEN I.M., GUVEN BAGLA A. and YAVUZ O.: Hismiogullari AA3, Histopathological changes in rat pancreas and skeletal muscle associated with high fat diet induced insulin resistance. Biotech. Histochem., 90 (7): 495-505, 2015.
45- FARISS W., CHAN B., PATEL M., VAN HOUTEN B and ORRENIUS S.: Role of mitochondria in toxic oxidative stress. Mol. Interv., 5 (2): 94-111, 2005.

46- CARRINGTON E.M., McKENZIE M.D., JANSEN E., MYERS M., FYNCH S., KOS C., STRASSER A., KAY W.T., SCOTT L.C. and ALLISON J.: Islet 3-Cells Deficient in Bcl-xL Develop but Are Abnormally Sensitive to Apoptotic Stimuli. Diabetes, 58 (10): 2316-23, 2009.

\section{فيتامين د يدعم قدرة خلايا- م فى البنكرياس على إعادة التشكيل

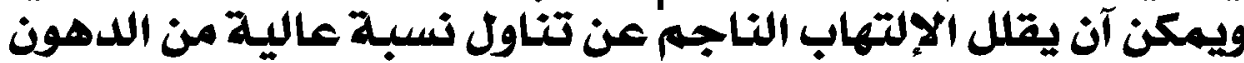

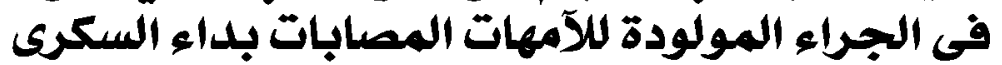

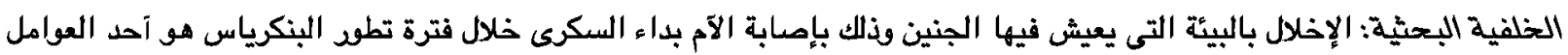

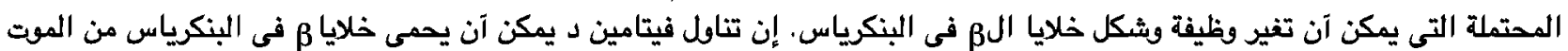
والضعف الوظيفى.

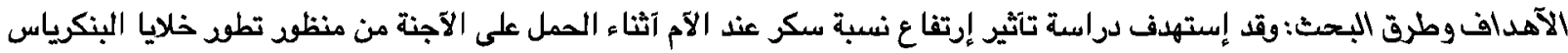

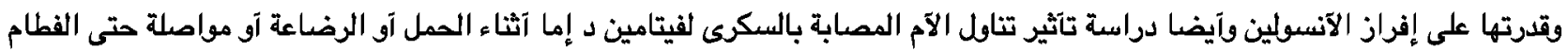

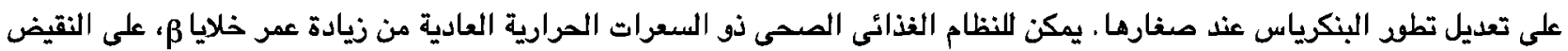

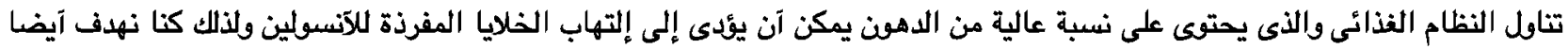

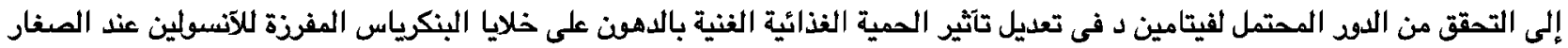

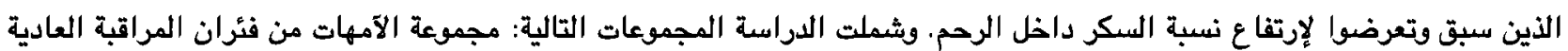

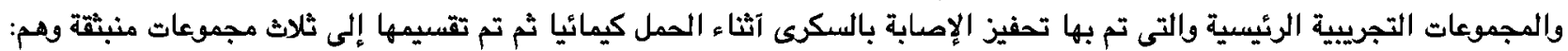

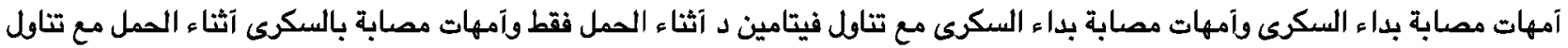

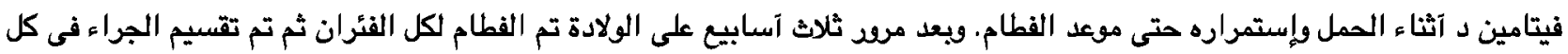

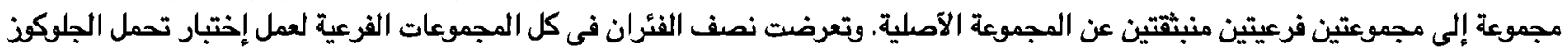

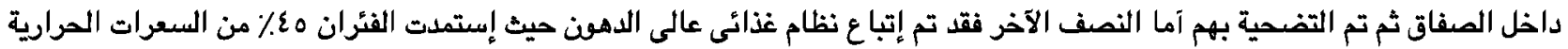

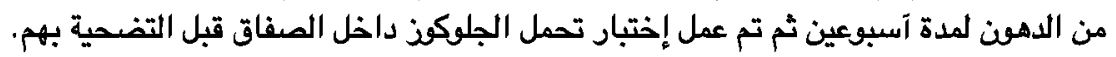

النتائج: وقد سجلت الدراسة تآثيرا واضحا لإرتقاع السكر آثناء الحمل على تطود نمو وقدرة خلايا البنكرياس عند الجراء وقدرة تأناول فيتامين د تحديدا حتى الفظام على حماية وذيادة قدرة خلايا البنكرياس على إنراز الآنسولين.

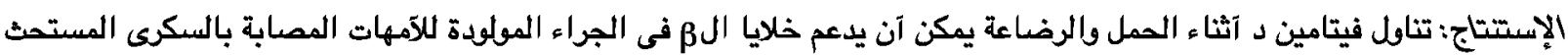

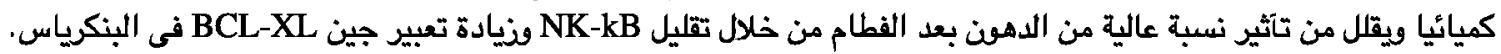

